\title{
PRESUMED CONSENT FOR ORGAN DONATION: AN INCOHERENT JUSTIFICATION
}

\author{
Vicente Formoso ${ }^{1}$, Sílvia Marina ${ }^{2}$, Miguel Ricou ${ }^{3}$
}

\begin{abstract}
The difference between supply and demand of transplantable organs is a global problem, and one of the most discussed measures aiming to solve it is the implementation of a presumed consent (opt-out) policy in cadaveric organ donation. This type of system is controversial when it comes to its direct effects on organ donation rates as well as its ethical base. We aim to present the latest perspectives concerning the ethical implications of the policy, especially regarding consent: its need, the coherence of presuming it and the policy's capacity to fulfill its requirements. From a community perspective, we advocate a default change in societies with an opt-out system, with a strong population education in that direction. The potential rights of family objection are also approached as well as the differences between theoretical discussion and concrete application of public policy.
\end{abstract}

Keywords: presumed consent, opt-out system, organ donation, post-mortem

\section{Presunción del consentimiento para la donación de órganos: una justificación incoherente}

Resumen: El desfase entre la oferta y la demanda de órganos para trasplantes es un problema mundial, y una de las medidas más discutidas para solucionarlo es la aplicación de una política de consientimiento presumido (opt-out) de la donación de órganos de cadáveres. Este tipo de sistema es controvertido teniendo en cuenta sus efectos directos sobre las tasas de donación de órganos, así como su base ética. Nuestro objetivo es presentar las últimas perspectivas sobre las implicaciones éticas, especialmente en lo que respecta al consentimiento: su necesidad, la consistencia de su presunción y la capacidad de cumplir sus requisitos. Desde el punto de vista comunitario, abogamos por un cambio por defecto en las sociedades con un sistema de opt-out, con una fuerte educación de la población a tal efecto. También se abordan los posibles derechos de la objeción familiar, así como las diferencias entre el debate teórico y la aplicación concreta de las políticas públicas.

Palabras clave: presunción del consentimento, sistema opt-out, donación de órganos, post-mortem

\section{Consentimento Presumido na Dação de Órgáos: Uma justificaçáo incoerente}

Resumo: A diferença entre a oferta e a procura de órgãos para transplantação é um problema global, e uma das medidas mais discutidas com vista à sua resolução é a implementação de uma política de consentimento presumido (opt-out) na doação de órgãos de cadáver. Este tipo de sistema é controverso ponderando os seus efeitos diretos nas taxas de doação de órgãos, bem como da sua base ética. O nosso objetivo é apresentar as últimas perspetivas relativas às implicaçóes éticas, especialmente no que diz respeito ao consentimento: a sua necessidade, a coerência da sua presunçáo e a capacidade em cumprir os seus requisitos. Numa perspetiva comunitária, defendemos uma mudança de default nas sociedades com um sistema opt-out, com uma forte educação da população nesse sentido. Os direitos potenciais da objeção familiar também são abordados, bem como as diferenças entre a discussão teórica e a aplicação concreta da política pública.

Palavras chave: consentimento presumido, sistema opt-out, doação de órgãos, post-mortem

\footnotetext{
${ }^{1}$ Faculty of Medicine of Oporto University, Portugal

Correspondence: vicente-rey@hotmail.com

${ }^{2}$ Faculty of Medicine of Oporto University and CINTESIS, Portugal. ORCID: https://orcid.org/0000-0003-4808-9000 Correspondence: silviamarina@outlook.com

${ }^{3}$ Faculty of Medicine of Oporto University and CINTESIS, Portugal. ORCID: https://orcid.org/0000-0002-8190-9587

Correspondence: mricou@med.up.pt
} 


\section{Introduction}

The revolutionary technique of organ transplantation appeared as an answer to a considerable and growing number of patients suffering from specific organ failures. This answer - as with all therapeutically innovative procedures — brought with it a set of questions, particularly from the ethics and legislative fields.

The discussion arises to consider not only the two usual perspectives — caregiver and patient- but also a new dimension: the donor. When considering the latter, the invasion of someone's (his/her corpse's) physical elements in such an extensive manner is justified mostly by the clinical benefit offered to others. At least in deceased donors. In living donors, we can say that the donor can get a psychological benefit from it.

This procedure uses two types of sources for transferable organic substrates: living and deceased donors. Concerning authorization and consent, the former can be asked about their willingness or not donate and discuss their concerns and motivations. The same cannot be said of the latter, hence the need to create specific regulations for deceased donors. In this last group, the decision and its respective statement will have to be made pre-mortem, so that if the individual becomes a potential donor, agents can proceed accordingly. There are two primary options for this regulation: a) explicit consent/opt-in: only individuals that have officially registered their will to donate are considered acceptable post-mortem donors, b) presumed consent/opt-out: all individuals are considered acceptable donors after death unless they have officially registered their dissent(1). Nevertheless, a common misunderstanding is under the opt-in legislation. In the UK, for example, even when people have expressed their willingness to donate joining to the NHS Organ Donor Register, the families are asked for consent, and their decision can prevail(2). Relatives of almost all brain-dead potential donors were approached about donation regardless if the person was registered as an organ donor(3).

The increase in waiting lists for organ transplantation is a global problem, with a growing need for organs and a deficient number of available donors. Therefore, more and more patients are piling up on a list that many believe underrepresents the real need for organs(4). Patients who remain for a long time on the waiting list may become too weak to undergo significant surgery and may be excluded(5).

There are several approaches available to bridge this problematic gap between supply and demand for organ donation. Despite the importance of attempting to reduce the demand for organ transplants(6), most of the debate is about increasing supply. One specific measure that has been indicated in the literature as having an important role in increasing supply $(7,8)$ is the implementation of a presumed consent policy on cadaver donation(2). Seventeen of the 35 Organization for Economic Co-operation and Development registered countries are classified as opt-out, and 18 as opt-in(9).

There are different perspectives to consider the direct results of an opt-out policy on the number of post-mortem organ donations. However, most authors agree that donation rates are higher in countries with opt-out legislation(10-12). Nevertheless, many authors argue that these results are not a direct consequence of the optout policy, but the effect of other confounding factors(13). They contend that the change to an opt-out policy is usually just one of several measures to increase the availability of transplantable organs; this creates difficulties for those tasked with evaluating the legislation's direct consequences(11).

Instead of the influence of the opt-in or opt-out systems in the increasing organs donations, we discuss issues that arise from the policies inherent in a post-mortem organ donation. Particularly, we reflect on presumed consent in post-mortem organ transplantation bearing in mind the associated ethical implications. A change in the type of consent is assumed.

\section{Presumed consent or opt-out system}

Respect for autonomy is a fundamental principle in medical care $(4,14)$. The concept of choice and consent takes a central role in modern societies. Therefore, if personal decisions are voluntary and 
based on adequate information, they must be respected; this is a system designed to contribute to the individual's well-being(15).

Post-mortem organ donation presents a particular case in respecting personal autonomy because any decisions and eventual actions must be made pre-mortem.

People still have interests after they pass away. Respecting people's decisions after death seems to be a socially desirable behavior(16). It is common to respect personal decisions after death about almost everything, including what to do with the body(17). Thus, the removal of organs without personal consent is considered wrong for the majority $(4,6)$.

The core ethical discussion concerning this postmortem organ donation relies upon the shortage of transplantable organs and the concerns about respecting personal autonomy (16) It is doubtful whether adopting an opt-out policy as a way to increase organ donations is ethically acceptable.

The term "presumed consent" is often used as a synonym for an opt-out system; actually, it is hard to say they have the same meaning. "Presumed consent" in its purest and most basic meaning applies to organ donation as follows: it is presumed that someone consents the removal of your organs when, during their lifetime, they have not registered their dissent. Using this term as a synonym for an opt-out policy is not correct, as it is just an example of possible justification for this type of system.

The most practical component of an opt-out policy is that the default position becomes the removal of the individual's organs. The person needs to make an official registration of dissent to avoid organ removal. The contrary happens under opt-in systems in which non-donation is the default procedure, and donation requires registration.

In the following section, the main topics of discussion concerning the adoption of an opt-out system will be approached, starting with the discussion of presumed consent itself as a possible jusfication for this type of policy.

\section{May consent be presumed?}

In the literature, several authors even question the validity of the concept, asserting that consent consists of an action and not a mental attitude or decision and that one cannot presume that an action has taken place if one knows for a fact it has not(17-19).

An invasive procedure in a medical emergency with an unconscious patient is a situation generally understood to involve presumed consent. However, the medical staff may be presuming the patient in question would consent if he/she could do so, and the justification for such a presumption relies on acting in the patient's best interests(18). The same cannot be said about organ donation. It is not legitimate to assume that it was in the individual's best interests to have his/ her organs removed(18). However, another author(20) argues for the importance of extended best interests in organ donation decisions, and this concept has been recognized in English law. The courts have made it clear that patients' best interests are not just to receive what is medically indicated, but are also taking into account their social, moral, spiritual, and religious values(20). This law supports a broad approach to evaluate the best interest, and this principle also applies to those who would wish to be organ donors.

We agree with Beauchamp and Childress(21) when they state about beneficence and nonmaleficence in medical care. They argue that the best interest of people should be linked with clinical dimensions alone. Moral, psychological, or other kind of benefits cannot be presumed because there are many differences between people.

\section{Implicit/tacit consent}

Instead of basing an opt-out system on the presumption of consent, it can be argued that we could base it on an implicit/tacit consent. When an individual fails to register an objection to consent, he/she is giving an implied consent $(22,18)$ if certain conditions are met: 1) the procedure associated to the consent must be a matter of general knowledge; 2) dissent registration must be practically effortless; 3) all information about the procedure and its consequences must be eas- 
ily accessible(18). In these conditions, it will be more accurate, to justify an opt-out system, to name the consent as implicit instead as presumed.

Nevertheless, different opinions arise regarding the mental attitude that underpins the action of consenting - in this case, implicitly. Some authors argue that if a consent procedure does not accurately reflect the individual's real opinion, will or rational decision; it can be considered immoral, similar to when one is using some manipulation to obtain something(22).

Other authors consider that if the individual does not register his/her objection, he/she is consenting regardless of his/her true feelings about the procedure. They argue that the mental attitude or intention is irrelevant if he/she consents. There is no difference between this and someone who signs a consent form without intending to consent(19).

Although we agree that —in an ideal situationimplicit consent could determine with reasonable accuracy, the exact will of the individual. It may be argued that, in truth, there is no way to understand the desires and opinions of others by anything apart from their actions(23).

Nevertheless, most of the authors believe that approval or willingness to donate is essential to the whole process(24). Some go even further, arguing that an opt-in system is the only way to provide clear evidence that the person wanted and intended to donate $(4,6)$. That is why some authors disagree with the opt-out system. They believe it is not possible to accurately infer consent from inaction, since it may happen for different reasons, such as ignorance or inertia towards official registration $(25,26)$. Of course, an opt-in system may be subject to symmetric criticism. It is possible that not all citizens are aware of the possibility to donate, or they do not know how to register their intent, or they have inertia to act on it (17).

\section{Is consent essential?}

The accepted premise is that it is wrong to make post-mortem organ transplantation without con- sent, and this is dogmatic for some authors. They claim that the only scenario in which it may be acceptable to remove an individual's organs is when there is clear evidence that this was his/ her will, without space for speculations or assumptions.

However, others assert that an opt-out policy can be justified based on a theory that rejects the very premise of the consent requirement, not based on any presumptions or inferences $(26,27)$, but based on a concept of "normative consent." According to this idea, it is wrong to refuse consent to something that it is morally right for the majority of the population. So, if it is wrong for a person to refuse to donate their cadaveric organs, their consent may not be necessary(27).

This concept would apply to an opt-out system. People do not have to register themselves as donors, and there is room for people with strong anti-donation feelings. These latter people have the power to register their rejection and not be subjected to the intervention $(26,28)$. Thus, the new premise is that donation is always permissible unless the individual refuses. The refusal would have the power to change the prior status quo. In this case, consent for transplantation would not be applicable(26).

It is argued that this concept justifies a policy of organ conscription - the indiscriminate procurement of organs - unbalancing a supposedly democratic system in favor of totalitarianism(29). Its advocates disagree, stating that this system maintains voluntary status by allowing people the possibility to register as non-donors(24) and preserving personal autonomy. Finally, an opt-out policy would have the objective of facilitating potential donations, not because of the subject's consent, but because they do not object to it (5).

\section{Individuality vs. community: easy rescue}

The process of organ donation demands not only a discussion from the individual's point of view but also a focus on the community. Transplantation should be a community endeavor because it can only be achieved through organ donation(24). Several authors argue that post- 
mortem organ donation represents a situation of easy rescue since a person can save someone's life (or at least enhance their quality of life) at little or no $\operatorname{cost}(26,27,30)$. For this reason, there is a duty to donate that some compare/contrast to a refusal to help someone in need(27). According to Snyder(31), a person must rescue others from harm if they can do it at little or no cost to themselves. The author calls to this proposal a duty of easy rescue, and state that a post-mortem organ transplantation qualifies as a case of easy rescue.

Nevertheless, because there is a possibility that the moral significance of the action represents a high cost from the individual's point of view (or even his/her family's), he/she has the right to register his/her objection at all times $(26,28)$.

Other authors support an even closer connection between the individual and the community. In a democratic society facing such a severe problem, there may be justifications to limit some rights that may constrain cadaver donations in order to protect the potential recipients at $\operatorname{risk}(32)$. Following this line of thought, it can even seem justifiable to resort to a system in which the right to object would be dependent on the reason presented or even a situation in which there is no right for refusal. However, for practical and political reasons, it may seem better to allow any individual who feels this inclination - as well as the motivation to act upon it - the right to register as a non-donor(30).

It is suggested - not as a justification but as a potential effect of the establishment of this policy - that knowledge regarding organ donation may help people understand how they can be autonomous and at the same time invested in their community's interests(30).

Regarding this notion of easy rescue: some authors contend that it is currently advocated as a duty to provide necessary assistance in an emergency, but its employment in such an invasive procedure would be going too far; treating "people" as a means to an end and not as an end in itself(6). Even so, some authors suggest that we can compare post-mortem organ donation with an autopsy. In many countries, autopsies are often required by law, without the individual's $(18,33)$ or their family's consent, even though they can also be considered to be a violation of the physical integrity of the corpse. Some authors argue that if an autopsy is ethically acceptable considering the individual's rights and the community interests, it should be ethically acceptable to perform similar interventions when the principle at play is much more important: the preservation of life(33).

\section{Defaults}

The real difference that comes with a change of policy from opt-in to opt-out systems can be seen as changing the default position from non-donation to donation(18). It seems that the change in default could have several consequences.

In several contexts, one can say that inertia interposes between the wishes of an individual, the act of making a decision and acting upon the decision $(4,26)$. This affects donation rates in opt-in systems, in which they can be much lower than the reported will to donate(34). It is almost unanimously agreed that whichever policy is implemented, it will inevitably be affected by this phenomenon(19).

It is a fact that default positions affect personal choices(34). In their decisions, people generally feel they need to have strong reason to deviate from the default stance; in cases of doubt, the default is chosen more often(17). The study of Davidai, Gilovich, and Ross(35) showed that different default positions changed the very meaning people attached to being a donor, from being altruistic when they donate to just accomplishing their moral obligation. Participation or nonparticipation as donor depends mostly on the individual and the collective meaning that is assigned to the choice at hand. When the default is organ donation, the act seems like the natural choice everyone chooses unless some extraordinary factor renders the individual reluctant to donate. When the default is not to donate, the act appears to be something noteworthy and exceptional, not something one would do without motive(17).

Some authors find the change of meaning that comes with a change in default status to be a neg- 
ative consequence. In their opinion, an opt-out system turns the act of donation into a default position rather than a selfless act of solidarity(34) or a voluntary gift(4), depriving it of its altruistic meaning. They even argue that some recipients find it easier to accept the organs if they know they were voluntarily given(4). Others oppose this perspective, stating that the main objective should be to save lives rather than make people feel good about donating(5); the principal value of the donation is instrumental, not expressive(19). Besides, making the morally correct process easier does not invalidate or diminish its significant value(19).

Specifically arguing in favor of an opt-out system, several authors believe that the choice considered to be morally correct should be the default, leaving the burden of registration to people opposing it $(17,19,23)$. From the community's point of view, some say that one positive change possibly brought about by an opt-out system would be a change in mentality. It could promote an understanding that this should be the expected behavior of any citizen(36) while underlining the value of community involvement towards the com$\operatorname{mon} \operatorname{good}(30)$. A change in this direction may represent the establishment of a new perspective, facing donation as an acceptable and natural part of dying(10).

\section{Is the removal of organs from people who do not agree worse than non-donation of the peo- ple who do agree?}

Whatever the policy in place, opt-in or opt-out, there is no doubt there will be mistakes $(17,22)$. By leaving the burden of registration to those who dissent, there is a risk that some people will have their organs removed against their will because they never registered their opinion(37). However, using an opt-in policy would cause some willing donors' organs to be unused for the same reason(17). Can one say that the compromise of the right to self-determination is higher in the first than in the second case(5)?

In this case, the severity of each fault must be compared with consideration to the two different rights' values. On the one hand, we have the right to refuse organ donation - and the requi- site cadaver operation - without consent. On the other hand, we have the right to decide on the organs' use(22). Despite the consequences, some authors vehemently defend that action without consent would be more objectionable than inaction despite consent(16).

\section{Family}

An opt-in system may help assure families that the deceased wanted to donate his/her organs. In these cases, the patient's intent is officially registered $(22,24)$. On the other hand, an opt-out system may allow greater protection for individuals who do not want to donate, since there is an official registry of their desire, which could serve as a guide for uncertain family members $(5,23)$. Consulting the family during the decision process may be seen as a safeguard for either system(4).

According to a family's viewpoint, a presumed consent may not be considered the best justification for the removal of a loved one's organs. The families seem to consider that a passive choice has been made, so their opposition is more justified. The perception that relatives have about the deceased's wishes about organ donation is thought to be the strongest predictor of a family's decision $(39,40)$. If the default position is to donate organs, the acceptance of this stance by the family will probably be higher.

Should a family's opposition to organ donation prevent the procedure? In the first place, it should be difficult for families to make a decision facing the inherent emotional problems associated with the love being lost (32). However, families usually know what action is in the patient's best interest because they usually know him/her better than the medical team. If the patient's decision is officially registered, it would be more difficult to justify any deviation from the patient's written opinion even, as we stated before, this is possible in the UK, for example $(2,3)$.

However, organ removal against the will of the family can damage the doctor-patient-family relationship(4). Nevertheless, giving the families the final decision is equivalent to the devaluation of the deceased's decisions $(5,6,14)$ and contradicts the respect for individual freedom(24). 
Despite these concerns, it may be unreasonable to consider a system that does not include families. It can be essential to avoid public discomfort(14) towards the donation program or even the national health system. Besides the inherent importance of the family's feelings(14), their support is also essential for providing information about the deceased that may be relevant to the procedures(4).

\section{Final considerations}

The literature detailing the effects of implementing an opt-out system suggests that there is a positive effect on donation rates, but it is difficult to establish causality $(11,12)$. In turn, the implementation of this type of system creates complexities. The argument traditionally raised is that there is a presumed consent if the person has not been registered in the national register of non-donors. It is argued that the majority of people would agree to the organ donation, even if they do not take the initiative to register as organ donor due to lax attitudes regarding the subject or by not wanting to prepare for the moment of their death. The literature does not support this argument. Logically, there is not much sense in maintaining a default position of non-organ donation if most people would agree to give their organs post-mortem. This apparent contradiction is justified through the presumed consent, which is not reinforced by the literature.

Presumed consent has been associated with an opt-out system, assuming that a person consented to the removal of their organs if, in life, he/she did not register their dissent. In our opinion, and the same line of reasoning as other authors $(17,18)$, there remains an incoherence in presuming an action that we know has not occurred. Presumption of consent is generally accepted for an invasive procedure in a medical emergency where the patient is unable to consent, thus allowing an action for the best interests of the patient(18). The same cannot be said about organ donation since it is not done in the best clinical interest of the patient. Moreover, consent cannot be accurately inferred through inaction; this may be due to a lack of information or inertia regarding official registration $(4,5,25)$.
In this context, we consider that a change of the default would be justifiable, rather than a presumed or implicit consent. Instead of being presumed based on inaction, it could be assumed that, given the reduced cost and the social benefit provoked, the norm would be to donate. Anyone who legitimately did not agree would have to make an effort to register as a non-donor. A default change is only possible if a majority of people agree with a donation.

The role of the family should be considered in a system like this to decrease the potential for unfair decisions that are inherent in any decision-making process. We argue that in an opt-out system, where the default would be organ donation, the family's opinion should be considered unless the person is registered as a non-donor. The purpose of the default change would be to promote the idea that we would all be donors after death. Of course, there remains the possibility of someone being against this change of premise and lacking the information to avoid it(28). However, this probability will likely be lower in a society where the default stance is organ donation. When the majority of people agree with an idea, those who disagree usually search for more information in order to develop stronger arguments and convictions. The family opinion should be considered in these situations to reduce the probability of injustices. Organ donation should be avoided if the family is unanimously against it.

The main reason for defending this idea is that we agree it will always be better to give organs than not to give them. However, we respect each other's beliefs and convictions, and we understand that the cost of giving organs would be too high for some people. Based on the belief that most people will agree with post-mortem donation, we advocate for societies with a current optout system to change the default and initiate a campaign of education and information for their population regarding this paradigm change. Giving organs after death can be valuable to society. Nonetheless, it should be clear that anyone who disagrees will be respected in their non-donation decision, regardless of their motivation. We need to understand if this default stance in an opt-out system impacts levels of non-donor registration. If so, it would be a sign that this option is more 
valid for increasing the number of donors (in comparison with an opt-in system) and is fairer to those who do not want to be organ donors. We believe this can promote greater social justice without depriving individuals of their autonomy(30).

\section{Acknowledgements}

This article was supported by FCT - Fundação para a Ciência e a Tecnologia, I.P., within CINTESIS, Unidad de I+D (referencia UIDB/4255/2020).

\section{References}

1 .

Roels L, Rahmel A. The European Experience. Transplant International: The Official Journal of the European Society for Organ Transplantation 2011; 24: 350-367.

2. Bird SM, Harris J. Time to move to presumed consent for organ donation. BMJ 2010; 340: c2188. DOI: https://doi. org/10.1136/bmj.c2188

3. Rudge CJ. Organ donation: opting in or opting out. British Journal of General Practice 2018; 68(667): 62-63. DOI: https://doi.org/10.3399/bjgp18X694445

4. Simillis C. Do we need to change the legislation to a system of presumed consent to address organ shortage. Medicine Science and the Law 2010; 50: 84-94.

5. Rieu R. The potential impact of an opt-out system for organ donation in the UK. Journal of Medical Ethics 2010; 36: 534-538.

6. Garwood-Gowers A. Time to address the problem of post-mortem procurement of organs for transplantation occurring without proper pre-mortem consent. European journal of health law 2013; 20: 383-408.

7. Shaw D. Presumed evidence in deemed consent to organ donation. Journal of the Intensive Care Society 2018; 19(1): 2-3.

8. Willis BH, Quigley M. Opt-out organ donation: On evidence and public policy. Journal of the Royal Society of Medicine 2014; 107: 56-60.

9. Arshad A, Anderson B, Sharif A. Comparison of organ donation and transplantation rates between opt-out and opt-in systems. Kidney International 2019; 95: 1453-1460. DOI: https://doi.org/10.1016/j.kint.2019.01.036

10. Bendorf A, Pussell BA, Kelly PJ, Kerridge IH. Socioeconomic, demographic and policy comparisons of living and deceased kidney transplantation rates across 53 countries. Nephrology 2013; 18: 633-640.

11. Bilgel F. The impact of presumed consent laws and institutions on deceased organ donation. The European Journal of Health Economics 2012; 13: 29-38.

12. Horvat LD, Cuerden MS, Kim SJ, Koval JJ, Young A, Garg AX. Informing the debate: rates of kidney transplantation in nations with presumed consent. Annals of Internal Medicine 2010; 153: 641-649.

13. Boyarsky BJ, Hall EC, Deshpande NA, Ros RL, Montgomery RA, Steinwachs DM. Potential limitations of presumed consent legislation. Transplantation 2010; 93: 136-140.

14. Cherkassky L. Presumed consent in organ donation: is the duty finally upon us. European Journal of Health Law 2010; 17: 149-164.

15. Cronin AJ, Harris J. Authorisation, altruism and compulsion in the organ donation debate. Journal of Medical Ethics 2010; 36: 627-31.

16. Hammami MM, Abdulhameed HM, Concepcion KA, Eissa A, Hammami S, Amer H. Consenting options for posthumous organ donation: presumed consent and incentives are not favored. BMC Medical Ethics 2012; 13: 32. DOI: https://doi.org/10.1186/1472-6939-13-32

17. Hartogh G. Tacitly consenting to donate one's organs. Journal of Medical Ethics 2011; 37: 344-347. DOI: http://dx.doi. org/10.1136/jme.2010.038463

18. Hartogh G. In the best interests of the deceased: a possible justification for organ removal without consent. Theoretical medicine and bioethics 2011; 32: 259-269.

19. Saunders B. Opt-out organ donation without presumptions. Journal of Medical Ethics 2012; 38: 69-72.

20. Coggon J, Brazier M, Murphy P, Price D, Quigley M. Best interests and potential organ donors. BMJ 2008; 336: 13461347. DOI: https://doi.org/10.1136/bmj.39575.561898.94

21. Beauchamp T, Childress J. Principles of biomedical ethics. Oxford University Press; 1994.

22. Wispelaere J. Tacitly opting out of organ donation: too presumptuous after all. Journal of Medical Ethics 2012; 38: 73 74. 
23. Saunders B. Opt-out donation and tacit consent: A reply to Wilkinson and De Wispelaere. Journal of Medical Ethics 2012; 38: 75-76.

24. Glazier AK. The principles of gift law and the regulation of organ donation. Transplant international: Official journal of the European Society for Organ Transplantation 2011; 24: 368-372.

25. Wilkinson TM. Opt-out organ procurement and tacit consent. Journal of Medical Ethics 2012; 38: 74-75.

26. Manson NC. Normative consent is not consent. CQ: the international journal of healthcare ethics committees 2013; 22: 33-44.

27. Saunders B. Normative consent and opt-out organ donation. Journal of Medical Ethics 2010; 36: 84-87.

28. Saunders B. Normative consent and organ donation: a vindication. Journal of Medical Ethics 2011; 37: 362-363.

29. Potts M, Verheijde JL, Rady MY, Evans DW. Normative consent and presumed consent for organ donation: a critique. Journal of Medical Ethics 2010; 36: 498-499.

30. Nelson JL. Internal organs, integral selves, and good communities: opt-out organ procurement policies and the separateness of persons. Theoretical medicine and bioethics 2011; 32: 289-300.

31. Snyder J. Easy Rescues and Organ Transplantation. HEC Forum 2009; 21(1): 27-53. DOI: 10.1007/s10730-009-90869

32. Cronin AJ, Harris J. Authorisation, altruism and compulsion in the organ donation debate. Journal of Medical Ethics 2010; 36: 627-631.

33. Pereira A. Transplantation of organs and tissues and some reflections on the "solidarity" of the human cadaver in Portugal. European journal of health law 2011; 18: 55-63.

34. Van Dalen HP, Henkens K. Comparing the effects of defaults in organ donation systems. Social Science \& Medicine 2014; 106: 137-142.

35. Davidai S, Gilovich T, Ross LD. The meaning of default options for potential organ donors. PNAS 2012; 109(38): 15201-15205. DOI: https://doi.org/10.1073/pnas.1211695109

36. Saunders J. Bodies, organs and saving lives: the alternatives. Clinical Medicine 2010; 10: 26-29.

37. Wellesley H. A nudge in the right direction for organ donation-but is it enough. BMJ 2011; 343: d5726.

38. Lin Y, Osman M, Harris A, Read D. Underlying wishes and nudged choices. Journal of Experimental Psychology Applied 2018; 24(4): 459-475. DOI: http://dx.doi.org/10.1037/xap0000183

39. Chandler JA, Connors M, Holland G, Shemie SD. Effective requesting: a scoping review of the literature on asking families to consent to organ and tissue donation. Transplantation 2017; 101(5S) Suppl 1: S1-S16. DOI: 10.1097/ TP.0000000000001695

40. Walker W, Broderick A, Sque M. Factors influencing bereaved families decisions about organ donation: an integrative literature review. West J Nurs Res. 2013; 35: 1339-1359. DOI: 10.1177/0193945913484987

Received: January 15, 2021

Accepted: February 12, 2021 